JTRM | Vol. 1 | No. 1 | Tahun 2019

\title{
Pengaruh Waktu Heat Treatment Terhadap Karakteristik Ceramic Coating Berpengikat Fosfat pada Baja Karbon Rendah
}

\author{
Dewi Idamayanti, Beny Bandanadjaja, Andreas Yosafat \\ Jurusan Teknik Pengecoran Logam, Politeknik Manufaktur Bandung \\ Email: benybj@polman-bandung.ac.id
}

\begin{abstract}
Informasi
Artikel:

ABSTRAK

Received:

2 Januari 2019

Accepted :

4 Maret 2019

Available

1 Desember 2019

Baja karbon rendah merupakan material yang biasa digunakan dalam industri penanganan batu bara, tapi memiliki ketahanan erosi dan korosi yang rendah. Oleh karena itu, dilakukan pelapisan ceramic coating berpengikat fosfat. $\mathrm{Al}(\mathrm{OH}) 3$ dan $\mathrm{H} 3 \mathrm{PO} 4$ digunakan sebagai bahan dasar binder. Partikel ceramic yang digunakan adalah Al2O3 dan SiC. Pada pembuatan ceramic coating berpengikat fosfat ini dilakukan heat treatment selama 5 jam. Sehingga dilakukan heat treatment pada ceramic coating berpengikat fosfat selama 1 jam, 3 jam dan 5 jam untuk mengetahui pengaruh waktu heat treatment terhadap karakteristik ceramic coating. Hasil karakterisasi menggunakan XRD menunjukkan berlinite sebagai pengikat antar partikel ceramic. Pengamatan menggunakan SEM menunjukkan semakin lamanya waktu heat treatment semakin banyak vacancy yang terbentuk. Dilakukan pengujian erosi untuk mengetahui ketahanan erosi ceramic coating. Berdasarkan hasil pengujian erosi, dihasilkan nilai erosion rate ceramic coating dengan partikel $\mathrm{SiC}$ sebesar $7,5 \mathrm{mg} / \mathrm{Kg}$ dan tanpa partikel SiC sebesar $14,2 \mathrm{mg} / \mathrm{Kg}$. Kemudian dilakukan pengujian ketahanan air, didapatkan losses dari ceramic coating sebesar $0,074 \%$. Hasil dari keseluruhan karakterisasi yang dilakukan menunjukkan, bahwa semakin lama waktu heat treatment ketahanan erosi dan ketahanan air meningkat pada rentang waktu heat treatment $1-5$ jam.
\end{abstract}

\section{Kata Kunci:}

Ceramic coating

Baja

Fosfat

Perlakuan panas

Berlinite

\begin{abstract}
Low carbon steel is a material commonly used in the coal handling industry, but has low erosion and corrosion resistance. Hence, there is often a decrease in performance due to the work environment that causes erosion and corrosion. To deal with decreasing performance of low carbon steel, phosphate-bonded ceramic coating is used. Ceramic coating utilizes the chemical reaction of a monoaluminium phosphate (MAP) binder with Al2O3 (alumina) which produces a berlinite (AIPO4) as a binding phase between ceramic particles. SiC (silicon carbide) and alumina are ceramic particles which is used in this research. To produce phosphate-bonded ceramic the heat treatment for 5 hours is carried out, which is less efficient in its application. Phosphatebonded ceramic was heated for 1 hour, 3 hours and 5 hours to determine the effect of heat treatment time on phosphate bonded ceramic characteristics. After characterization using XRD, it was found that the phase which binds ceramic particles is berlinite. The SEM results show that heat treatment time affects the morphology of ceramic coating. The longer the heat treatment time, the more vacancies are formed. To determine erosion resistance of ceramic coating, erosion test is conducted. Based on the result of erosion test, erosion rate of ceramic coating with addition of SiC particles was $7.5 \mathrm{mg} / \mathrm{Kg}$ and without SiC was $14.2 \mathrm{mg} / \mathrm{Kg}$. To make sure of berlinite, water resistance test was carried out, because berlinite is not soluble in water and will not lose mass significantly if it's immersed in water. The losses obtained from the water resistance test were $0.074 \%$. The results of the overall characterization performed showed that the longer the heat treatment time, erosion resistance and water resistance increased in the span of 1 to 5 hours.
\end{abstract}




\section{Pendahuluan}

Material St-37 digolongkan sebagai baja karbon rendah memiliki form ability yang baik, karena memiliki matrix ferritic [1]. Namun, material St-37 memiliki ketahanan erosi yang rendah dengan nilai erosion rate sebesar $20 \mathrm{mg} / \mathrm{Kg}$ [2]. Ketahanan erosi dan korosi yang rendah sering menjadi masalah dalam penggunaan material St-37 terutama dalam industri penanganan batu bara, seperti komponen sistem konversi batu bara, grinding equipment dan transport pipelines. Masalah tersebut dapat diatasi dengan penggunaan ceramic coating pada St-37, untuk melindungi logam dari korosi akibat temperatur tinggi dan meningkatkan ketahanan erosi [3].

Ceramic coating diaplikasikan dengan metoda CBPC yang dibentuk dengan reaksi antara kation logam dan anion fosfat [4]. Aluminium phosphate ceramic merupakan salah satu jenis dari metoda CBPC, dimana heat treatment dengan temperatur yang rendah dibutuhkan untuk mencapai ikatan kimia [5]. Fasa pengikat yang paling efektif dari sintesis aluminium phosphate ceramic adalah monoaluminium phosphate [3]. Setelah melalui proses heat treatment pada temperatur rendah akan menghasilkan fasa berlinite sebagai fasa yang mengikat antara partikel ceramic [4].

Berdasarkan hasil penelitian Idamayanti dkk [2], [6] didapatkan nilai erosion rate ceramic coating berpengikat fosfat dengan penambahan partikel $\mathrm{SiC}-\mathrm{Al}_{2} \mathrm{O}_{3}$ sebesar $5 \mathrm{mg} / \mathrm{Kg}$ dan tanpa partikel SiC sebesar $8 \mathrm{mg} / \mathrm{Kg}$. Idamayanti dkk [2], [6] membuat ceramic coating berpengikat fosfat dengan proses heat treatment selama 5 jam.

Lamanya proses heat treatment selama 5 jam kurang efisien apabila diaplikasikan di lapangan, karena terlalu lama. Oleh karena itu dilakukan penelitian yang berfokus pada pengaruh waktu heat treatment terhadap karakterisasi ceramic coating berpengikat fosfat dengan partikel SiC dan tanpa partikel SiC. Karakterisasi yang dilakukan untuk menentukan pengaruh waktu heat treatment adalah dengan pengujian $X$-Ray Diffraction, Scanning Electron Microscope, ketahanan erosi dan ketahanan air. Diharapkan hasil dari penelitian ini dapat menghasilkan waktu heat treatment ceramic coating berpengikat fosfat yang lebih efisien.

\section{METODE PENELITIAN}

Ceramic coating berpengikat fosfat dibuat dari $\mathrm{Al}_{2} \mathrm{O}_{3}-\mathrm{SiC}$ sebagai partikel keramik dan $\mathrm{Al}(\mathrm{OH})_{3}-\mathrm{H}_{3} \mathrm{PO}_{4}$ sebagai bahan pembuat binder. Alumina $\left(\mathrm{Al}_{2} \mathrm{O}_{3}\right)$ yang digunakan berukuran $52,1-195 \mu \mathrm{m}$ dengan kandungan unsur oksigen (62,95\%), aluminium (35\%) dan kalium $(2,05 \%)$. Sedangkan silicon carbide $(\mathrm{SiC})$ yang digunakan berukuran $15,9-33,8 \mu \mathrm{m}$ dengan kandungan unsur karbon (39,47\%) dan silikon (60,53\%). Asam fosfat $\left(\mathrm{H}_{3} \mathrm{PO}_{4}\right)$ dan aluminium hidroksida $\left(\mathrm{Al}(\mathrm{OH})_{3}\right)$. Komposisi ceramic coating seperti pada Tabel 1. 
Pengaruh Waktu Heat Treatment Terhadap Karakteristik Ceramic Coating Berpengikat Fosfat pada Baja Karbon Rendah

Tabel 1 Komposisi Ceramic Coating dengan partikel SiC

\begin{tabular}{lll}
\hline No. & Bahan & Banyaknya \\
\hline 1. & Aluminium hidroksida $\left(\mathrm{Al}(\mathrm{OH})_{3}\right)$ & $11,212 \mathrm{gr}$ \\
2. & Asam fosfat $\left(\mathrm{H}_{3} \mathrm{PO}_{4}\right)$ & $42,25 \mathrm{gr}$ \\
3. & Aquades & $27,5 \mathrm{gr}$ \\
4. & Binder : partikel keramik & $1: 1$ \\
\hline
\end{tabular}

Pembuatan binder dilakukan dengan mencampurkan aluminium hidroksida dengan asam fosfat yang sudah diencerkan dengan aquades pada temperatur $100{ }^{\circ} \mathrm{C}$ selama 20 menit dan dilakukan pengadukan secara terus-menerus. Binder yang dihasilkan adalah mono aluminium phosphate (MAP). Pada pembuatan binder mengacu pada reaksi kimia berikut:

$$
\mathrm{Al}(\mathrm{OH})_{3}+3 \mathrm{H}_{3} \mathrm{PO}_{4} \rightarrow \mathrm{Al}\left(\mathrm{H}_{2} \mathrm{PO}_{4}\right)_{3}+3 \mathrm{H}_{2} \mathrm{O}
$$

Binder yang sudah jadi kemudian dicampur dengan partikel keramik. Sehingga, dihasilkan 2 jenis ceramic coating, yaitu dengan partikel $\mathrm{SiC}(60 \%)+\mathrm{Al}_{2} \mathrm{O}_{3}(40 \%)$ dan partikel $\mathrm{Al}_{2} \mathrm{O}_{3}$ $100 \%$. Ceramic coating diaplikasikan dengan metode pengkuasan pada permukaan baja karbon rendah yang sudah dibersihkan dengan methanol. Setelah diaplikasikan, dikeringkan pada temperatur kamar selama 2 jam. Kemudian dilakukan proses heat treatment sebagai berikut:

Temperatur $\left({ }^{\circ} \mathrm{C}\right)$

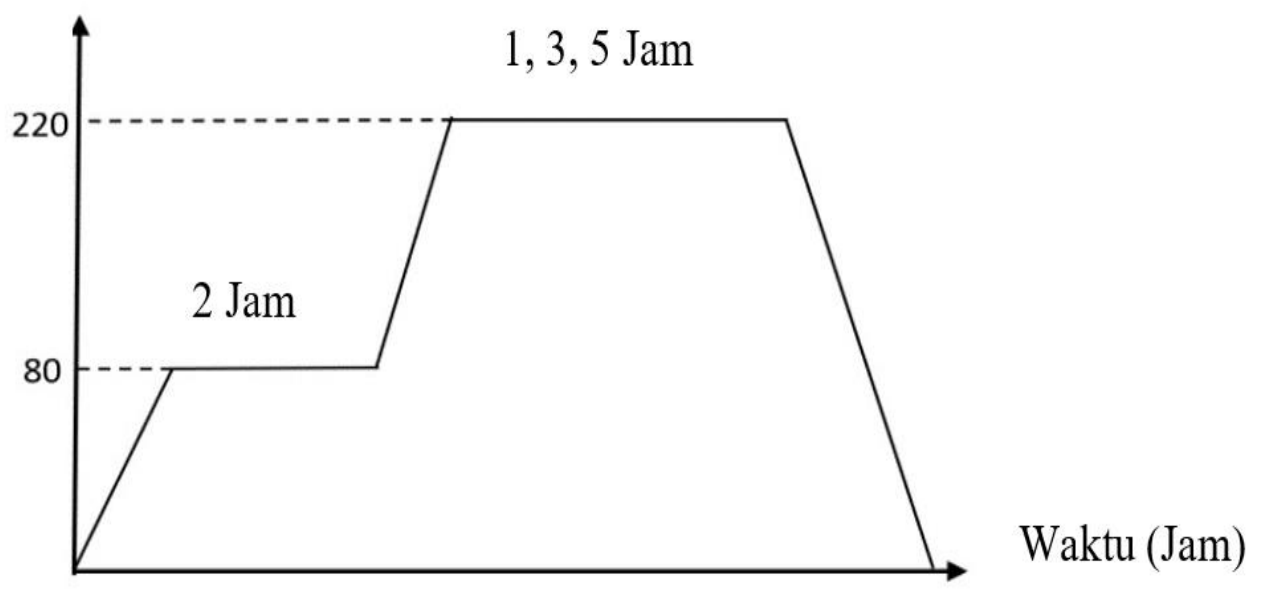

Gambar 1. Kurva proses heat treatment ceramic coating

\section{HASIL DAN PEMBAHASAN}

Pengujian XRD dilakukan untuk mengetahui komposisi ceramic coating berpengikat fosfat dengan partikel SiC dan tanpa partikel SiC. Didapatkan hasil sebagai berikut: 
Dewi Idamayanti, Beny Bandanadjaja, Andreas Yosafat

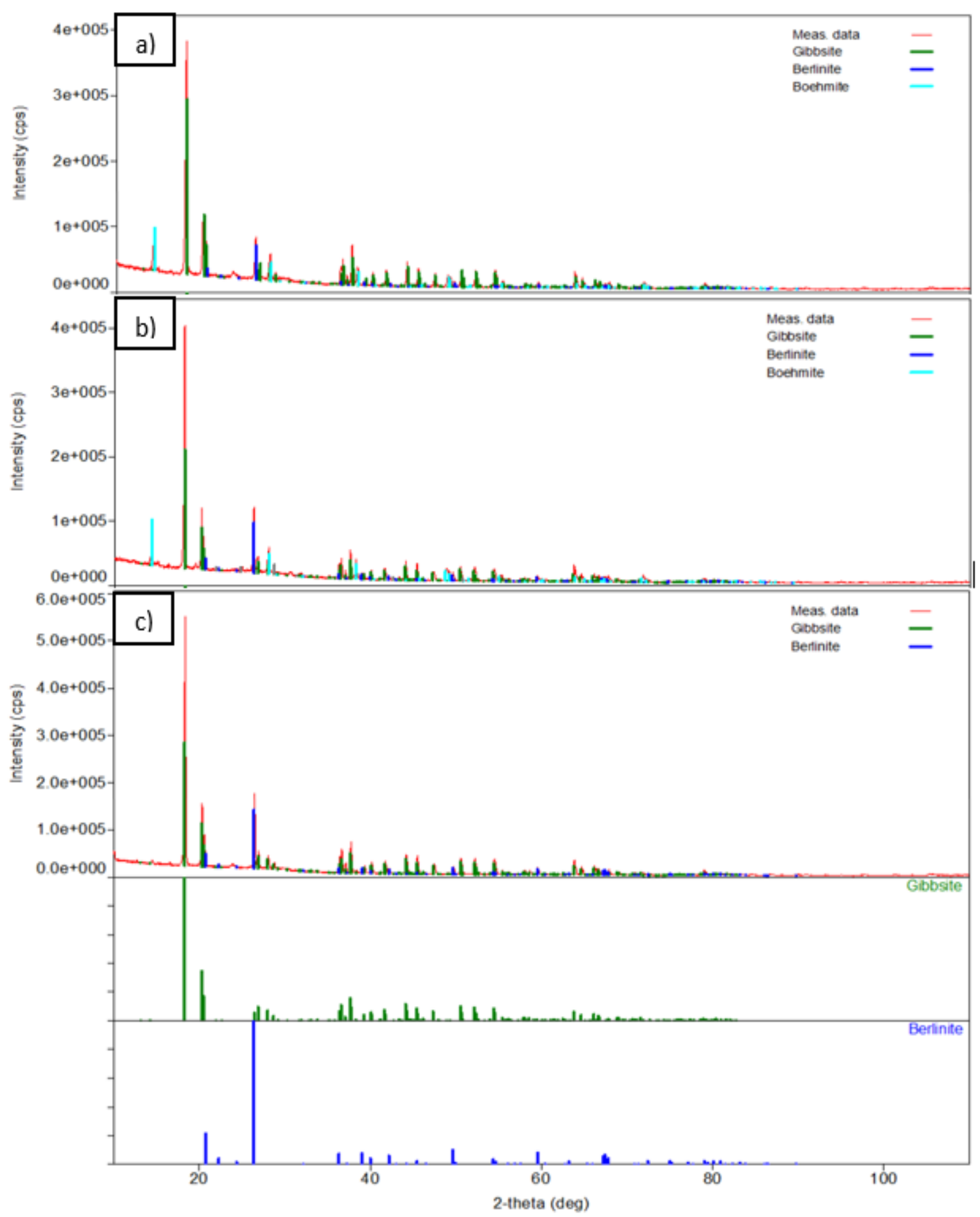

Gambar 2. Hasil XRD ceramic coating tanpa SiC a) 1 jam, b) 3 jam, c) 5 jam

Pada hasil XRD didapatkan peak berlinite $\left(\mathrm{AlPO}_{4}\right)$, yang menjadi fasa pengikat antar partikel. Berlinite merupakan hasil transformasi dari MAP setelah heat treatment pada temperatur 220 ${ }^{\circ} \mathrm{C}$ [3]. Dari hasil XRD terlihat bahwa semakin lamanya waktu heat treatment jumlah berlinite semakin banyak. Berlinite juga terbentuk dari hasil reaksi alumina dengan MAP [7].

$$
\mathrm{Al}_{2} \mathrm{O}_{3}+\mathrm{Al}\left(\mathrm{H}_{2} \mathrm{PO}_{4}\right)_{3} \rightarrow 3 \mathrm{AlPO}_{4}+3 \mathrm{H}_{2} \mathrm{O}
$$


Pengaruh Waktu Heat Treatment Terhadap Karakteristik Ceramic Coating Berpengikat Fosfat pada Baja Karbon Rendah

Gibbsite merupakan salah satu bentuk dari alumina, yang memiliki kelarutan diatas temperatur pembentukan berlinite [4]. Sedangkan boehmite merupakan bentuk alumina yang memiliki kelarutan dibawah temperatur pembentukan berlinite [4].

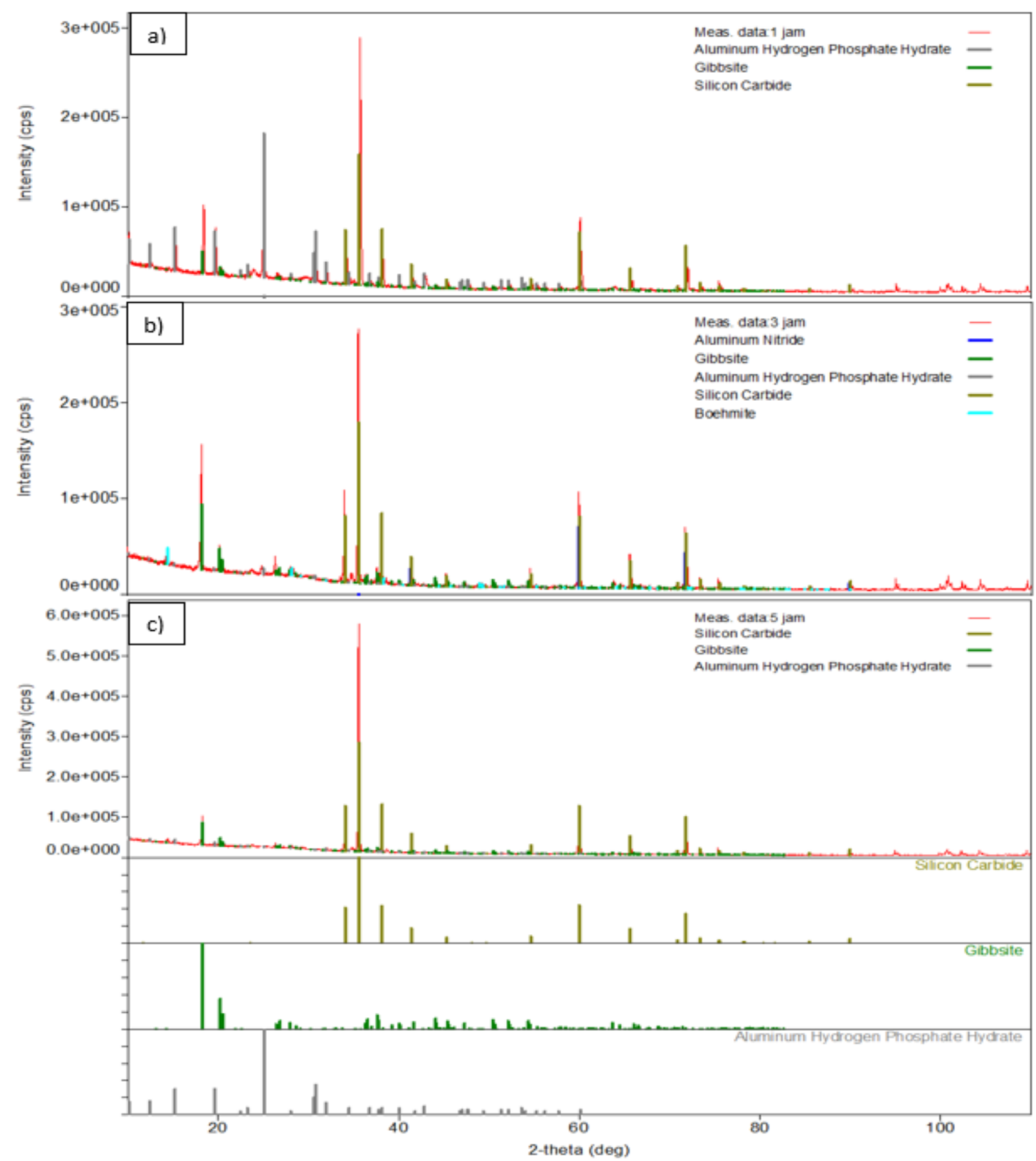

Gambar 3. Hasil XRD ceramic coating dengan SiC a) 1 jam, b) 3 jam, c) 5 jam

Pada hasil XRD 1 jam terlihat peak MAP yang tinggi, menunjukkan banyaknya jumlah MAP. Namun, pada waktu 3 jam dan 5 jam jumlah MAP sangat sedikit. Tidak adanya peak berlinite diduga karena mesin XRD tidak dapat membaca jumlah berlinite yang terlalu sedikit. Akan tetapi, dengan berkurangnya MAP seharusnya ada fasa lain yang terbentuk, yaitu berlinite yang terbentuk dengan heat treatment pada temperatur $220^{\circ} \mathrm{C}$ [3]. 
Gibbsite merupakan bentuk dari alumina yang memiliki kelarutan di atas temperatur pembentukan berlinite, sedangkan boehmite merupakan bentuk dari alumina yang kelarutannya di bawah temperatur pembentukan berlinite [4]. Sehingga masih terdapat peak boehmite pada 3 jam waktu heat treatment. Pada waktu 1 jam seharusnya masih terdapat peak boehmite, akan tetapi diduga boehmite terutup oleh MAP.

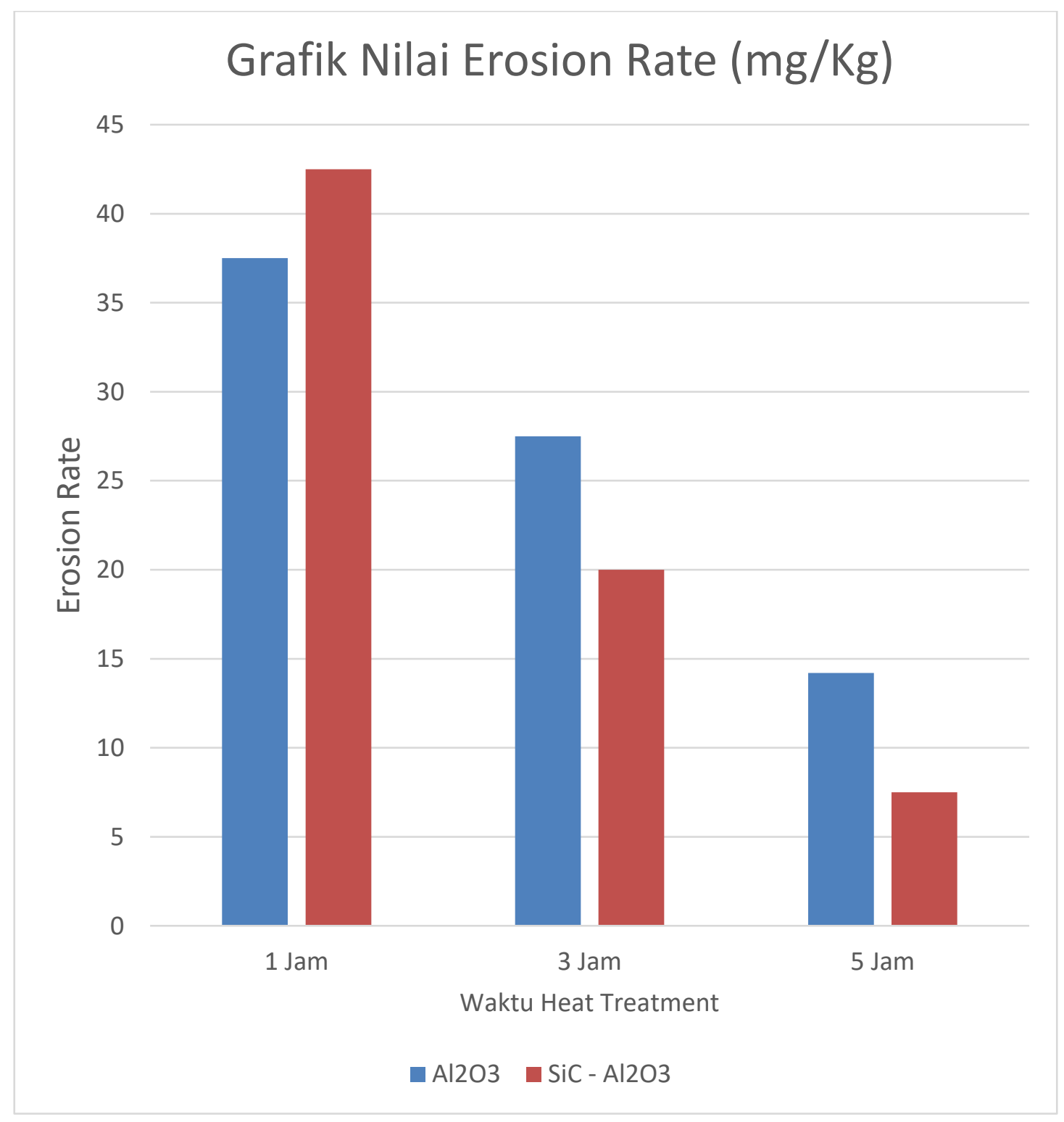

Gambar 4. Grafik nilai erosion rate ceramic coating

Dari hasil uji erosi, terlihat bahwa dengan semakin lama waktu heat treatment ketahanan erosi ceramic coating dengan partikel SiC maupun tanpa partikel SiC semakin baik dengan berkurangnya nilai erosion rate. Namun dengan penambahan partikel SiC ceramic coating semakin tahan erosi, karena semakin keras suatu material ketahanan erosinya semakin baik [8]. Kekerasan SiC dalam skala Moh's >9, sedangkan kekerasan erodent material (alumina) sebesar 9 [9]. 
Pengaruh Waktu Heat Treatment Terhadap Karakteristik Ceramic Coating Berpengikat Fosfat pada Baja Karbon Rendah

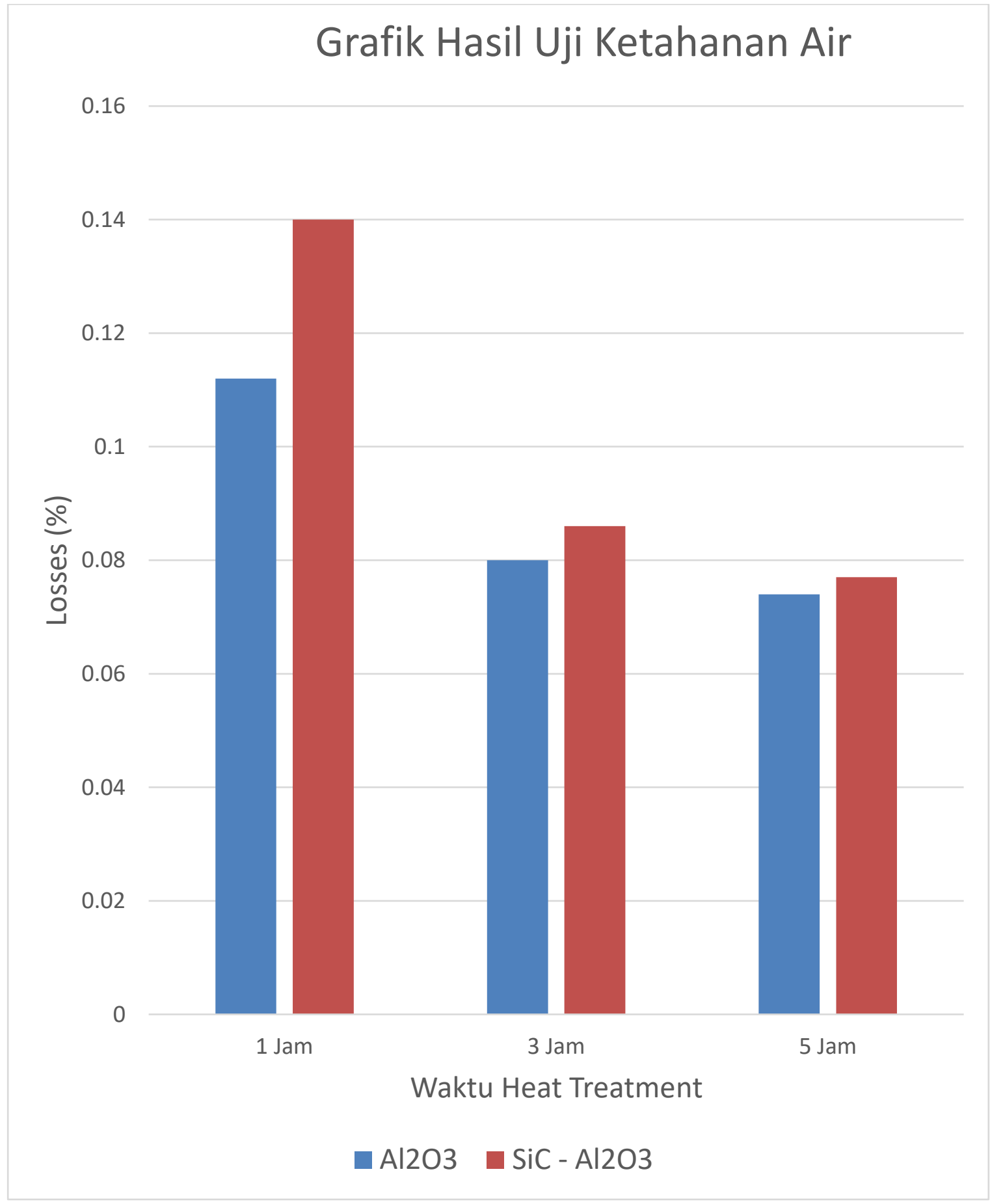

Gambar 5. Grafik hasil uji ketahanan air ceramic coating

Hasil uji ketahanan air menunjukkan ceramic coating dengan partikel SiC dan tanpa partikel $\mathrm{SiC}$ semakin tahan air dengan semakin lamanya waktu heat treatment. Sedangkan dengan penambahan partikel SiC ceramic coating semakin tidak tahan air. Sebab fasa berlinite terbentuk dari reaksi MAP dengan alumina dan dengan proses heat treatment di $220{ }^{\circ} \mathrm{C}$, dimana fasa berlinite merupakan fasa yang tidak larut dalam air [4]. Sehingga jumlah alumina yang digunakan akan berpengaruh pada jumlah berlinite. 

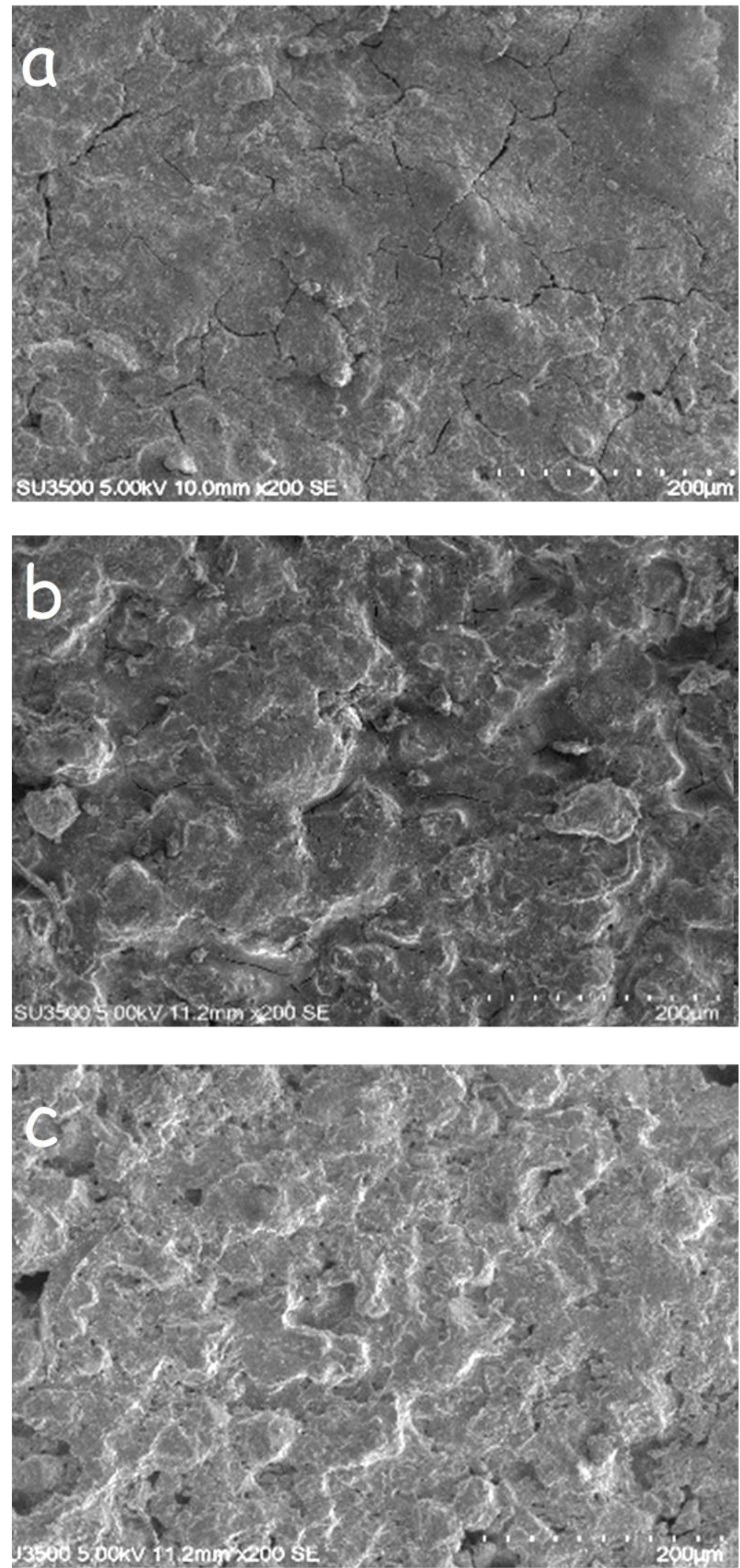

Gambar 6. Permukaan ceramic coating tanpa SiC a) 1 jam, b) 3 jam, c) 5 jam 
Pengaruh Waktu Heat Treatment Terhadap Karakteristik Ceramic Coating Berpengikat Fosfat pada Baja Karbon Rendah
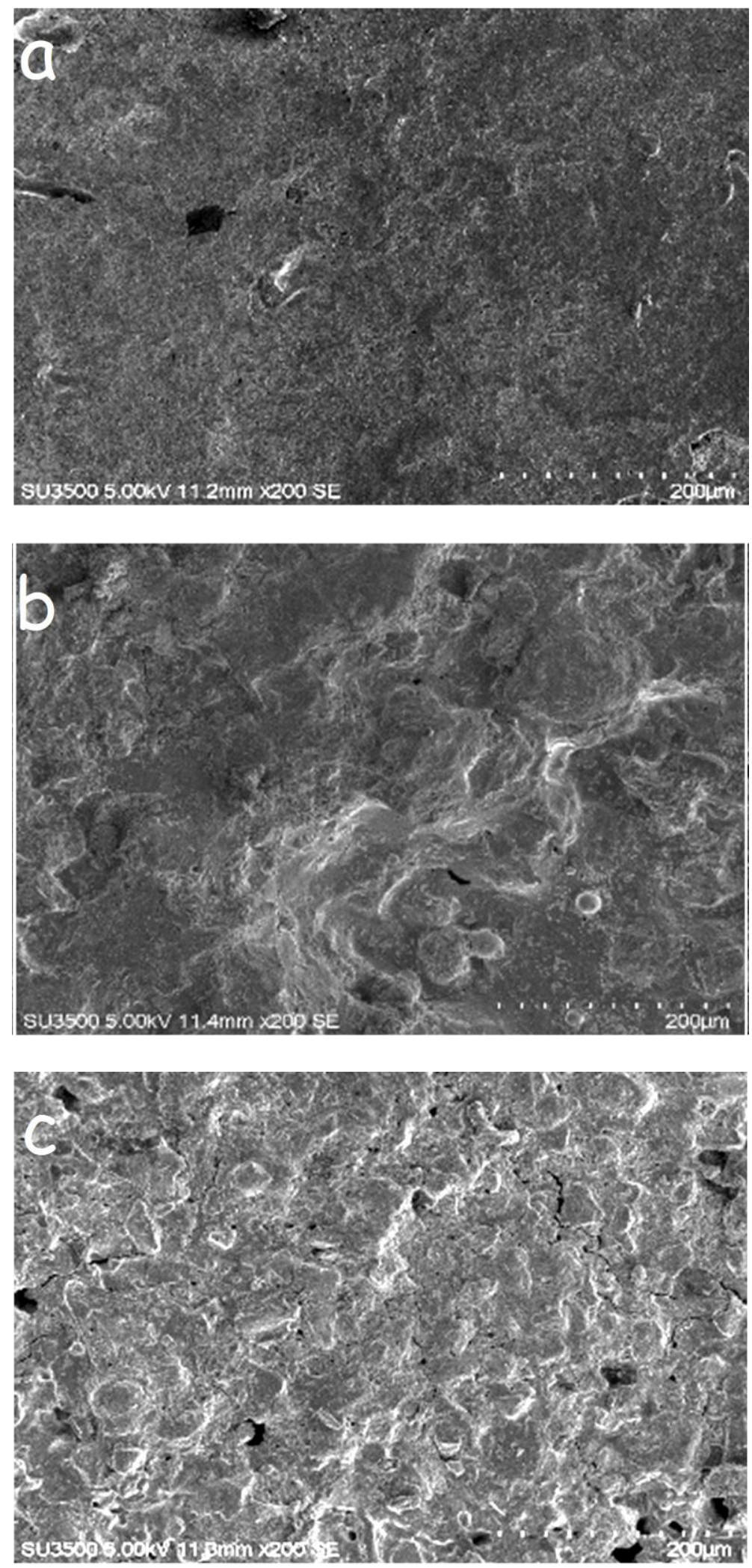

Gambar 7. Morfologi permukaan ceramic coating dengan SiC a) 1 jam, b) 3 jam, c) 5 jam

Morfologi permukaan ceramic coating dengan partikel SiC dan tanpa partikel SiC diamati dengan SEM, terlihat dengan semakin lamanya waktu heat treatment permukaan semakin tidak rata. Hal ini disebabkan oleh penyusutan yang terjadi selama proses heat treatment 
[10]. Sehingga partikel keramik semakin nampak ke permukaan. Vacancy dan crack yang terbentuk juga semakin banyak. Hal ini disebabkan oleh penguapan air yang terjadi selama waktu heat treatment [7].

\section{KESIMPULAN}

Kesimpulan dari hasil penelitian pengaruh waktu heat treatment terhadap karakteristik ceramic coating berpengikat fosfat pada baja karbon rendah adalah:

1. Semakin lama waktu heat treatment, nilai erosion rate dan losses ketahanan air semakin rendah, untuk ceramic coating dengan $\mathrm{SiC}$ ataupun tanpa SiC.

2. Pada variasi waktu heat treatment selama 5 jam, dihasilkan ceramic coating dengan erosion rate terkecil, dengan partikel $\mathrm{SiC}$ sebesar $7,5 \mathrm{mg} / \mathrm{Kg}$ dan tanpa partikel $\mathrm{SiC}$ sebesar $14,2 \mathrm{mg} / \mathrm{Kg}$.

3. Pada variasi waktu heat treatment selama 5 jam, dihasilkan ceramic coating dengan ketahanan air paling baik. Didapatkan losses ceramic coating dengan partikel SiC sebesar 0,077\% dan tanpa partikel SiC sebesar 0,074\%.

\section{REFERENSI}

[1] G. Aggen et al., ASM Handbook, Volume 1, Properties and Selection: Irons, Steels, and High Performance Alloys Section: Publication Information and Contributors Publication Information and Contributors, vol. 1. 2005.

[2] D. Idamayanti, D. Ginanjar, B. Bandanadjaja, W. Purwadi, and N. Lilansa, "Erosion behaviour of alumina ceramic coating on mild steel by the modified composition of phosphate binder," IOP Conference Series: Materials Science and Engineering, vol. 541, no. 1. pp. $0120261-8,2019$.

[3] D. Chen, L. He, and S. Shang, "Study on aluminum phosphate binder and related $\mathrm{Al} 2$ O 3 -SiC ceramic coating," Mater. Sci. Eng. A, vol. 348, no. 1-2, pp. 29-35, 2003.

[4] D. Williams, "Chemically bonded phosphate ceramics," PCI-Paint and Coatings Industry, vol. 28, no. 2. pp. 15-27, 2012.

[5] E. Colonetti, E. Hobold Kammer, and A. De Noni Junior, "Chemically-bonded phosphate ceramics obtained from aluminum anodizing waste for use as coatings," Ceram. Int., vol. 40, no. 9 PART A, pp. 14431-14438, 2014.

[6] D. Idamayanti, I. L. Nurhakim, B. Bandanadjaja, W. Purwadi, and N. Lilansa, "Improvement of erosion resistance of alumina-phosphate ceramic coating on mild steel by SiC addition," in IOP Conference Series: Materials Science and Engineering, 2019, vol. 541, no. 1 .

[7] F. J. Gonzalez and J. W. Halloran, "REACTION OF ORTHOPHOSPHORIC ACID WITH SEVERAL FORMS OF ALUMINUM OXIDE.," Am. Ceram. Soc. Bull., vol. 59, no. 7, 1980.

[8] A. W. Ruff and S. M. Wiederhorn, "Erosion by solid particle impact.," TREATISE Mater. Sci. Technol., vol. 16, Erosi, pp. 69-126, 1979.

[9] A. V Levy and P. Chik, "The effects of erodent composition and shape on the erosion of steel," Wear, vol. 89, no. 2, pp. 151-162, 1983.

[10] J. Willis, T. A. Seiitz, S. J. Null, and J. W. Bohlen, "Method of Controlling Drying Stresses by Restricting Shrinkage of Ceramic Coating," vol. 2, no. 12, pp. 4-7, 2003. 